Meta

Journal des traducteurs

Translators' Journal

\title{
Translation of in, on, at and over into Spanish in a Technical Context
}

\section{Isabel Gonzales Pueyo}

Volume 40, numéro 1, mars 1995

URI : https://id.erudit.org/iderudit/003878ar

DOI : https://doi.org/10.7202/003878ar

Aller au sommaire du numéro

Éditeur(s)

Les Presses de l'Université de Montréal

ISSN

0026-0452 (imprimé)

1492-1421 (numérique)

Découvrir la revue

Citer cet article

Gonzales Pueyo, M. I. (1995). Translation of in, on, at and over into Spanish in a Technical Context. Meta, 40(1), 81-90. https://doi.org/10.7202/003878ar
Résumé de l'article

L'auteur étudie quatre prépositions locatives anglaises (in, on, at, over\} et leurs traductions espagnoles afin de découvrir lesquelles sont les plus usitées en anglais, dans un contexte technique et scientifique: elle analyse ensuite les traductions espagnoles possibles de ces prépositions au niveau syntaxique et leur utilisation en contexte selon leur prototypicité.
Ce document est protégé par la loi sur le droit d'auteur. L'utilisation des services d'Érudit (y compris la reproduction) est assujettie à sa politique d'utilisation que vous pouvez consulter en ligne.

https://apropos.erudit.org/fr/usagers/politique-dutilisation/ 


\section{TRANSLATION OF IN, ON, AT AND OVER INTO SPANISH IN A TECHNICAL CONTEXT}

M. Isabel Gonzalez Pueyo

Universidad de Zaragoza. Zaragoza. Spain

\section{Résumé}

L'auteur étudie quatre prépositions locatives anglaises (in, on, at. over) et leurs raductions espagnoles afin dé décourrir lesquelles sont les plus usitées en anglais, dans un conte vie technique a't scientifique: elle analyse ensuite le's traductions espagnoles possibles de ces prépositions au niveau syntaxique e't leur utilisation en contevte selon leur prototypicité.

\section{INTRODUCTION}

The purpose of this paper is the study of four English locatives within a technical and scientific context and their translation into Spanish.

Peter Newmark (1981: 24) says that the translation of prepositions is one of the major causes of linguistic obscurity as they perform different functions in a variety of languages. But. undoubtely, the basic English locatives $i n, o n, a t$ and over are those which present more difficulty to Spanish speakers. The difficulty encountered in translating those prepositions is due to the fact that their semantic meanings are interrelated. The Modern Language Association (1960): 25) pointed out that the Spanish preposition $e n$ is very often translated as, in, on, at, and relatively infrecuently as $t o$. for or of.

The English preposition in is in many contexts equivalent to the Spanish prepositions en and sobre, but, at the same time, sobre is equivalent to the English on and over and in some contexts can be translated as above and around. In addition, prepositions en and sobre are often neutralized by prepositions $d e$ and por when translating in. on and over. These associations can be diagrammed as follows:
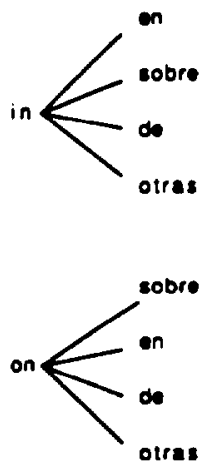
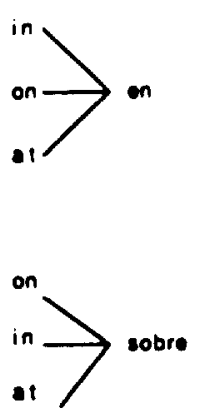
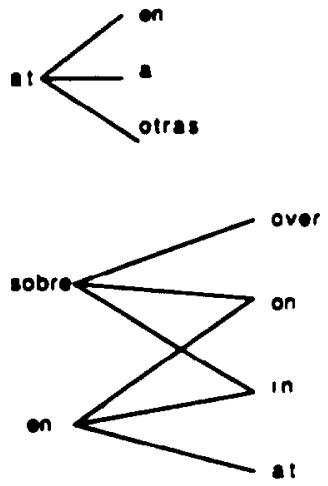
On the other hand. Spanish speakers learning English tend to overuse English in regardless of whether the context require in. on or at. As Cancino (1980) pointed out this might be due to the following facts:

- there are close phonetic similarities between English in and Spanish en:

- the syntactic uses of English in and Spanish on are very similar;

the semantic ranges of English in and Spanish e'n are partly identical.

Similarly, English preposition at, in its most common locative use. conveys a sense of vague location which corresponds perfectly to certain uses of the Spanish preposition ('n, as can be seen in the following examples:

- at onc end: ch un extremo:

- at the surface: en la superficite:

- al some places: en a/gunos hagerres:

- at the source: en la fiac'nte.

It is, thus, the purpose of this study to identify the most common English locatives - which are in. on, at. orer. in a technical context and their translation into Spanish. This was done to fulfill the following purposes:

a) to find out which spatial English prepositions were most frequently used in the different texts:

b) to analyse the different translations into Spanish at the syntactic level and their uses in the context according to their prototypicity.

\section{PROTOTYPICITY}

The concept of prototype was established by Rosch (1973) and consists of identifying the best coample's that illustrate the most basic use of that preposition (Rosch 1973: 112) and analysing the semantic features found in those hest examples. The best examples are those that come to mind more readily to the native speakers of a language (Rosch ct al. 1976). Thus, for example the most prototypical use of the preposition in would be the one that posseses the largest number of characteristics associated with the category. that is, when the noun governed by the preposition is an example of a container with sharp boundaries ( $e^{\prime}$.g.: "There is a pencil in the hox"). Rosh also argues for degrees of prototypicality. Examples of the different translations are shown in the appendix.

\section{DATA ANI) RESUILTS}

The data for this study consisted of three technical books on the following topics:

- thermodinamics,

- computational mathematics.

- electricity,

and some articles from bilingual semi-technical magazines such as Scicmific American. The examples from the books were translated from English into Spanish by specialists on the required subject, though not necensarily specialists in the English languatge.

Initially, the results obtained showed a strong tendency to translate Einglish prepositions $i n$, $\left(m\right.$ and $a t$ as ${ }^{\prime} \prime$. The second important translation was sobre for preposition on and $d e^{\prime}$ for prepositions in and $m$. Preposition at showed more polysemy in its translation into Spanish. In the text of mathematics prepositions in. on and at were often translated as para, as in the examples: 
- the function is continuous at $x=\mathbf{a}$

la función es continua para $x=a$

- that converges on $/ z-a /$ que comerge para lo.s z rale's que

- if $f$ and $g$ are polynomials in $x-a .$.

Si 'f' $y$ ' so' polinomios para / en x-a

Preposition over was always translated as sobre, or in its place as the adverbial locution 'encima de'.

Results of the different texts in percentages are shown in table 1.

The examples from the corpus have been grouped according to their degrees of prototypicity and further they have been compared with their translation into Spanish. The study showed firsly that prepositions in technical texts are closer to their prototypical meaning and, secondly a growing tendency in the Spanish system Io translate prepositions in and on, as, e'n.

\section{THE DOMAIN}

The semantic domain of spatial English prepositions is more restricted than in the Spanish system and very often the use of a locative will depend on the context, as in the examples:

"at the comer" (en la esquina) versus "on the comer" (en ef rincón); "at the hospital" (purpose), versus "in the hospital" (3-dimensional space) both translated into Spanish as en.

However, the semantic field of Spanish prepositions is not so easily boundered, since their meanings are often interrelated, and they have the ability to commute among them in many contexts

Polysemy - the restricted number of prepositions (20 in the Spanish system, 65 in the English system) could account for their great polysemy. As an example, the Spanish dictionary DRAE registers 18 meanings for preposition $a, 18$ for $d e, 6$ for $e n .5$ for entre. 14 for sobre. Furthermore, the meaning of prepositions often depends on the context. Thus, the meaning of the preposition $d e$ is different in each of the following contexts: "la casa de mi padre" (my father's house), "vaso de plata" (a silver glass), "la calle de la derecha" (the street on the right) or "el tren de Londres" which in its turn has three different possible meanings: "el tren con dessino a Londres" (the train to London), "el tren procedeme de Londres" (The train from London) and a third more neutral which explicits the relationship between object and place, i.e. "el tren que es de Londres" (The London train) or the train which "belongs" to London. Similarly, the English dictionary Longman gathers 18 meanings for preposition in, 19 for on and 15 for at.

Synomimy is more prominent in the Spanish system being a constant cause of translation problems. For example the lexical group "at night" (temporal use of at) can by translated as "de moche". "durante la noche". "por la noche". In fact, there exists a great number of examples (see García Yebra 1982: 823).

Semantic polysemy is also considerable as can be seen in any bilingual dictionary. García Yebra (1982: 782-786) gives the following translations for the prepositions studied:

IN: $a$, hajo, con. de, en, sobre, dentro de (extension and modulation techniques).

ON: a costa de a orillas de. hajo, contra, de. encima de, mediante para. por, segün, so. sobre, tras.

AT: A la orilla de, al horde de, ante. conn. de, en, junto a, por: 
Prepositional meaming - prepositions, on the other hand. can modify the meaning of the governing tenn ats oceurs in the English system with verbs such as go in, go (1IIt. go' up), go andar, go om, etc.

Likewise, in the Spanish system prepositions can modify the term which they govern, as happens with many lexical groups.

This can be seen in some verbs followed by a preposition, such as the verb frafar followed by the preposition d', the meaning of which depends on the context:

\begin{tabular}{|c|c|}
\hline Le lratio de scmuries & (to give someone a title) \\
\hline le' lrutride' lecen & (to call someonc a f(nol) \\
\hline ratri de' excapar & (he iricd to cscape) \\
\hline rosta de hacerts & $($ try lo doit) \\
\hline trala de medicina & (il is aboul medicine) \\
\hline
\end{tabular}

(examples from the DRAF)

\section{TRANSI.ATION OF PRFPOSITIONS}

When translating from one language into another there are always some operations which take place at the syntactic level. These operations are obvious laking into account the different syntactic struclure of both languages.

However, syntax in technical language is far more simple than everyday language. Syntactic simplicity compensates somehow the density of the information content. This seems logical considering that the first purpose of technical writers is 10 comunicate their information content as clearly and precisely as possible.

Nevertheless, the syntax in Spanish texts is often more complicated than in Finglish, due to the marked presence of hypotaxis in Spanish language as opposed to the more frequent use of parataxis in English (Varyuez Allora 1977).

Let us first examine the different translation operations that have taken place in our corpus, considering the prepositional syntagm from a formal point of view and following the theories of Newmark (1980), Vasquez y Allora (1977). and Vinay (1976).

- The first operation observed is the grammatical mamsposifiom or transformation. as in the examples:

To enable electrons in semiconductors to move

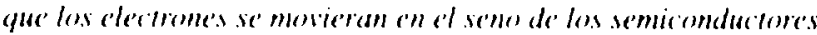

In the above sentence the group in semiconductors to move has been transformed into a subordinate clause in Spanish. In addition, a new lexical group has appeared: o'n ol seno de which conveys the idea of total interiority encountered in the most basic meaning of the preposition in. ()ther translations are not possible since there is syntactic incompatibily, as occurs in the sentence: loning air rwsh into the crankedse': permitiendo que el aire entre en ol cirter:

Similarly in the sentence :

atoms with nuclei at their center

atomos con sus nucleos a'n el c'mllat

there has been a transposition of the possesive their from comer to mackei.

- Grammatical transformation also oceurs in passive clauses. As the use of passive voice is restricted in the Spanish language, sentences such as:

it is placed; it is ohserved, it is used for, etc., so common in technical English are translated as se colecos, se observes, se wiliza. etc. into Spanish with se as an indeterminated subject. Example: 
In a gasoline engine fuel and air are mixed

En un motor de gasolina se mezclun el combustible y el aceite

The -ing form is also frequent in technical English, but the use of the gerund form is very restricted in the Spanish language (G.R.A.E.) thus, a kind of transformation is necessary, as in the examples:

When conducting electrons moving in the alumminium: Cuando los electrones de conduccion que se mueven en el interior del aluminio

the incoming air: el aire que entra

passing trough the tips: que atraviesa las puntas

All these lexical groups have been expanded through a relative subordinate clause in Spanish giving origin to a longer sentence.

- Often what is said in English with a preposition must be translated into Spanish by a complete clause, as otherwise it would not make sense. Thus:

The book on the table: el litro que esta sobre la mesa.

Sentences such as the one above are frequent in technical English. For example:

a) pumps the coolant through passages in the block and head: bombea el refrigerante por unos pasos que se encuentran en la culala.

b) the diagonal through the cube: la diagonal que atraviesa el cubo.

c) The flux 0 in the center leg: el flujo que circula por la columna central. clause.

- In these cases and similar the preposition has been expanded through a relative

In addition, the preposition in in the example $c$ ) has been traslated by the preposition por. Actually. Spanish en can not be used with verbs of movement whereas English prepositional system admits the use of in / on in these kind of instances: she is in the street (está en la (calle) and she walks in the street (anda por la calle). Nevertheless, Spanish en contains a range of extension which makes it compatible in certain contexts. For example the sentence:

By the J'R loss of currents that circulate in the material

Which translates as:

Por la pérdida de corriente que circula en el seno del material

It can be observed that the group in the material has been modulated and expanded through the lexical group en el seno de (or en el interior de) not being possible a literal translation (que circula en el material). An alternative translation could have been:

...que circula por la través de el material

Similarly, in many occasions the prepositions in or on instead of being expanded through a clause, are translated as de. Let us consider the following examples:

a) a book on the table

b) the trook on the table

The appropiate translation for a) is hay un libro en / sobre la mesa. and for b) el libro que está en / sobre la mesa, hut it could also be translated as el libro de la mesa. However it can be observed that in example b) the term which governs the English preposition is 
preceeded by the determinate article: in contrast to example a) where the indeterminate article is used. Likewise, spanish distinguishes between ser and estar (both; $t o$ be in English).

the protein solution in the glass cylinder: la soluc ioin proteinica del cilindro (i.e' que hay en). the water in the center of the container: el agua de' centro del comtenedor (i.e. que está en).

Dynamic lerbs normally found in process description, are often followed in technical English by a preposition which indicates the modality of the action. These prepositions are not translated into Spanish since their meaning is already implicit in the Spanish verbs. Examples:

the gases flow out the port: Ios gases salen por el arificio

the piston moves down: el pistin desciende

compressed air from the crankcase thows into the cylinder: el aire romprimide entra desde el cintert:

\section{CONCIUSION}

Literal translation of English prepositions in, an, at and ofer into Spanish is not always possible because their semantic meanings frequently overlap. and because there are some syntactic incompatibilities and neutralizations anong Spanish prepositions at the sentence level which makes it impossible.

However, in the context of technical and scientific English examined. locatives are closer to their most central or prototypical meaning and a considerable reduction of semantic extension can be observed in the use of prepositions. Polysemy and synonymy, on the other hand, were greater in semi-lechnical texts, making impossible a classification of the corresponding translations.

Preposition in and on have been generally translated as ${ }^{\prime} n$. On has been generally translated as sobre only in those cases where it was necessary to distinguish between the concepts of total interiority (English in) and superiority (English $\mathrm{on} / \mathrm{over}$ ). Otherwise $(\mathrm{n}$ has been prefered to solme' except in the mathematical context. Preposition over has been generally translated as subre or e'turima de (on top of ).

Spanish e'll and sobre' (IEnglish in and $(m)$ ) have been neutralized by prepositions de and $p o r$ in some specific contexts. Other translations were negligable.

The preposition a has been translated in general as en (locative use) or a (temporal use); in mathematics these prepositions are frequently translated as para.

The cross-linguistic study showed that distinct uses types or sub-categories of prepositions were expressed by the same preposition in both languages, giving evidence that similar mental processes connect the uses (Herskovits 1982).

\section{Pedagogical implications}

According to the results obtained a possitive transfer between $i n=e n, o n=e n /$ sobre and $a t=a / a$ can be observed. For this reason Spanish students will not have big difficulties in translating those prepositions from English into Spanish as long as they are aware of the subject matter, but there is a "legtrive tresnsfers from Spanish into English, so that Spanish speakers will tend to use in in contexts where $m$ or at should be used, on instead of over or in and of instead of in or $\mathrm{m}$. 
TABLE: 1

Percentages

\begin{tabular}{|c|c|c|c|}
\hline \multicolumn{4}{|c|}{ a) Thermodinamics } \\
\hline \multicolumn{2}{|c|}{ IN: $2(0)$} & ON: 116 & AT: 98 \\
\hline $\begin{array}{l}71 \% \text { en } \\
41 \% \text { en } \\
1.5 \% \text { para }\end{array}$ & $\begin{array}{l}1 \% \text { extensión } \\
1 \% \text { a / a través } \\
0.5 \% \text { sobre /con }\end{array}$ & $\begin{array}{ll}6.3 \% \text { en } & 3 \% \text { a } / \text { hacia } \\
19.5 \% \text { sobre } 1 \% \text { con } \\
7 \% \text { de } & 1 \% \text { ext. } \\
5 \% \text { para } & 0.5 \% \text { por }\end{array}$ & $\begin{array}{lr}58 \% \text { en } & 2 \% \text { por } \\
16 \% \text { con } & 2 \% \text { sobre } \\
10 \% \text { para } & 21 \% \text { sobre } \\
6 \% \text { de } & 4 \% \text { resto }\end{array}$ \\
\hline \multicolumn{4}{|c|}{ b) Mathematics } \\
\hline \multicolumn{2}{|l|}{$\begin{array}{l}75 \% \text { en } \\
23 \% \text { de } \\
3 \% \text { para } \\
1 \% \text { sobre }\end{array}$} & $\begin{array}{l}\text { ON: } 51 \\
71 \% \text { en } \\
12 \% \text { para } \\
13 \% \text { sobre } \\
4 \% \text { de }\end{array}$ & $\begin{array}{l}64 \% \text { en } \\
35 \% \text { para } \\
1 \% \text { de y sobre }\end{array}$ \\
\hline \multicolumn{4}{|c|}{ c) Electricity } \\
\hline \multicolumn{2}{|c|}{$\begin{array}{l}\text { IN: } 54 \\
89 \% \text { en } \\
9 \% \text { de } \\
2 \% \text { extensión } 16 \% \text { extensión }\end{array}$} & $\begin{array}{l}\text { ON: } 18 \\
50 \% \text { en } \\
22 \% \text { sobre } \\
6 \% \text { de } \\
6 \% \text { a }\end{array}$ & $\begin{array}{l}86 \% \text { en } \\
14 \% \text { para }\end{array}$ \\
\hline
\end{tabular}

\section{REFERENCES}

BENETT. D. C. (1975): Sparial and Tempeoral use of English Prepositions an Essay in Stratificarional Semantics. London, longman.

BRONDAL. V. (1950): Theoru des prepositums. Introduction d une seimantique ratiennelle, Copenhague.

CANCINO, M. (1980): First Language Transfer in the Aquisition of English Locative Prepositions and Genirues by Four Spanish Speakers. Unpublished doctoral disertation, Harvard University.

COSERIU, E. (1977): Los liniversoles lingüistices, Madrid. Giredos.

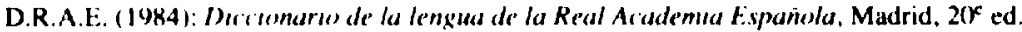

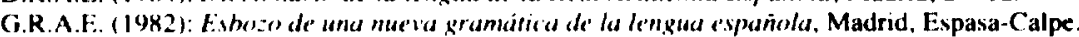

FOLKART, B. ( $|98|)$; "Lenseignentent de la traduction technique ; une approache formelle du discours technique", Revue de l' liniversité d"Olana, Vol. $15, \mathrm{n}^{\prime \prime} 3$.

GARCIA YEBRA. V. (1982): Téoria y prática de la traducrión. Vol. II, Madrid, Gredos.

Longman Dictionary of (ontemporary English (1978): Longman

HERSKoVITS, A. (1982): Space and the Preposmoms in English: Re'gularifies and frregularifi in a Complex Doman, II.M.I. 22(1)47I.

NEWMARK. P. (1481): Approaches ir Translation, Oxford Pergamon Press.

OUIRK. R. A. (1985): A (irammar of (omk'mporary Fnglish, London. Logman.

ROSCH. E. (147.5): "Cognitive Representation of Semantic Categories". Journal of Fiperimental Psycology. 104, pp. 192-23,3.

VA7.QUEZ, Y ALI.ORA. (i. (1977): Intredución a la raducfologia. Washington DD, Georgetown University Press.

VINAY, J.-P. et DARBELNET, J. (1976): Stwlisrique comparée du francais et de langlais, Paris. Nouvelle Ed.. Didier.

WIDDOWSON, H. (1974): "The Deep Structure of Discourse and the use of Translation", Explorafion in Applied linguistics, 1979, London, Oxford (Iniversity Press, pp. I0(0)-111. 


\section{APPENDIX}

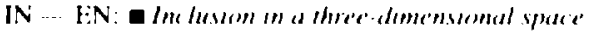

- Physical ohject contatumed in another

a) Examples of comtainers

- There are very tew molecules in the tube

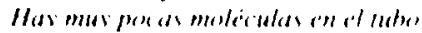

- ... In the intake mamituld

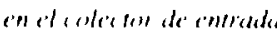

b) I or 2-dimensionil spice.

- This generates a high voltage un the secondary circull

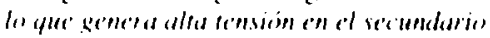

- For each pousil 'at in a comected open vel

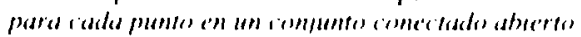

- The voltages induced in the w inding,

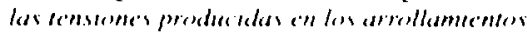

c) 3-dimensional space with fus/y twoundartes

a ...for several fuels hurn on anr

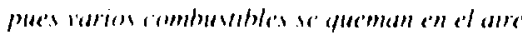

ain is cound Hils

ren sema rendes ale somede

- with cavilatioms in the oul tilm

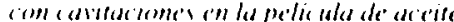

- sodium chloride in the uatter

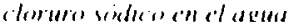

d) The lexated objects are holes, gapx's, etc.

a varying the number of holes in the fuel injector nomse

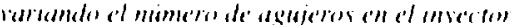

e) Inclusion in an angular ubject

- Point $A$ is in angle $B$

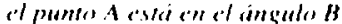

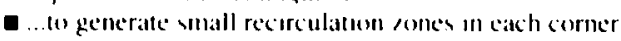

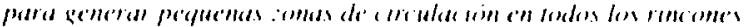

f) Restricted space or area:

in at matentic ficl

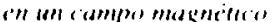

Exicnsional meaning

- in the fickl of programming

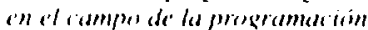

g) Object occupying part of another

a in the midalle of.

in muldsda, an el ientros de

- in the neighburghexet

en el contrones de

IN - I I :

a) Physical object formming part of intsther

- If $A$ and $B$ are ponts in I

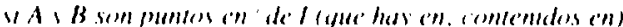

- electrons in a televison tube

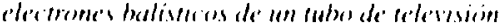

b) Object or entity an a highlighted enviromment

a hole in the wall

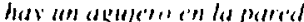

- the hole in the wall

ol asuleres de la pased

- The protein solutum in the glasn cylinder

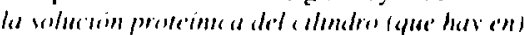


- the water in the center of the container el agua del ceniro del contenedor (que está en)

IN - POR

Extension:

- The flux $O$ in the center leg

al flujo O que circula por la columna central

- By the J'R loss of currents that circulate in the material

Por la perdida de corriente que circula en el seno del material

ON - SOBRE/EN

Superior posision in contact with a horizontal surface

a) Physical object supported by another:

- On the surface of a neutron star

in la superficicie de una e'strella de ne'urromes

- a function is analytic on an open ser.

una func ión e's anulimica a'n / sobre un sonjumto abiertes

- it creates a toryue on each molecule

crea un momenos de giro en cada molicula

b) Conceptualized as a line:

- The effect on the primary circuit

al cefero en/sohre el primario

- And recording the images on tiape

regestrar las imigenene's e'n rimba

c) Conceptualized as sides:

- on opponite legs of the core

en colummas opuessas al núcleo

d) Conceptualized as 'edges':

- on the edge of the beam

en sobre el horde de la liga

ON - SOBRE

a) Grouped by the sema movement:

- Transformers are wound on closed cores

los ransformidederes se devanan sobre micleos cerrades

- Pouring a layer of eom oil on the water

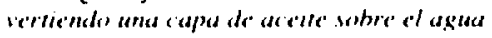

b) Contact versus interiority:

- ii is a free particle with no force on it

es una particula libre sobre la yue me actuan fuerzas

- the depossit in the cathode was grey

el deprisuse where al cuatrede erou gros

c) Tolal covering:

- ...a rational function is analytic on the plane..

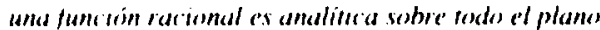

AT - A

Coincidence at a point in the time:

a) with magnitudes and values

- at the temperature

a la semperarura

a at specific frecuency

a frecuencia especifica

at full vollage

a tenssón mixuma 
AT $-\mathrm{EN}$

Coincidence at a point in the space: vague location:

a at the spark plug

en la bujia

- at the cathode

en el cátodo

- at point 'a'

en el purso' ' $a$ '

AT - PARA

In mathematics:

- the function is continuous at $\mathrm{x}=\mathrm{a}$

la función es continua para $x=a$ 